\title{
Use of the Potential Ecological Risk Index for Sediment Quality Assessment: A Case Study of Dam Lakes in the Thrace Part of the Marmara Region
}

\author{
Cem Tokatlı1 (1)
}

Cite this article as: Tokatli, C. (2019). Use of the potential ecological risk index for sediment quality assessment: A case study of Dam Lakes in the Thrace part of the Marmara Region. Aquatic Sciences and Engineering, 34(3), 90-95.

ORCID IDs of the authors: C.T. 0000-0003-2080-7920

'Trakya University, İpsala Vocational School, Department of Laboratory Technology, Edirne, Turkey

Submitted:

28.03.2019

Revision Requested

01.07.2019

Last Revision Received 24.07.2019

Accepted:

28.07.2019

Online published:

07.08.2019

Correspondence:

Cem Tokatlı

E-mail:

tokatlicem@gmail.com

(C) Copyright 2019 by Aquatic

Sciences and Engineering

Available online at

https://dergipark.org.tr/ase

\begin{abstract}
Ergene River Basin, which is known as a critically contaminated habitat, is located in the Thrace Part of the Marmara Region of Turkey. Altınyazı, Karaidemir, Kayalıköy, Kırklareli, Sultanköy and Süloğlu Dam Lakes are located in the Ergene River Basin in the Thrace Region, which has very large agricultural lands because of rich soil and many freshwater resources. They were constructed by DSi (State Water Works) in order to provide irrigation and drinking water and flood protection. The aim of this study was to evaluate the sediment quality of these artificial lentic ecosystems by investigating a total of 25 essential and toxic element accumulations and evaluate the ecological risks of toxic metals on the reservoirs by using Potential Ecological Risk Index ( $\left.R_{1}\right)$. Sediment samples were collected in the spring season (rainy) of 2018 from 15 stations and element concentrations were investigated by using an ICP-MS. According to the results of $R_{1}$ cadmium, lead and arsenic were found to be the highest ecological risk factors for the basin reservoirs.
\end{abstract}

Keywords: Thrace Region, Ergene Basin, Lentic Habitats, Toxic Metals, Sediment Indices

\section{INTRODUCTION}

Rapid growth of population, developments of industry and lack of environmental awareness cause significant environmental problems and decrease the freshwater quality (Köse et al., 2014; Tokatlı et al., 2016). Lacustrine habitats (artificial or natural) are among the most vulnerable freshwater bodies to pollution due to their exposure to point (eg. municipal and industrial wastewater) and non-point (eg. run-off from agricultural land) contamination sources in their drainage basins (Çiçek et al., 2014; Tokatlı et al., 2017a).

It is clearly documented that sediment may pose a serious risk factor on the water quality through the complicated biogeochemical exchanges. Therefore, the investigation of the sediment quality is an essential and prime component of aquatic ecosystem assessment research (Farom- bi, et al. 2007, Yu et al. 2011; Çiçek et al., 2019). Many indices have been developed to evaluate the environmental and ecological risks of toxic elements in surface sediments and one of the most widely used sediment indices is Potential Ecological Risk Index (R) (Çiçek et al., 2013; Tokatlı et al., 2017b; Maanan et al., 2018).

The Thrace Region of Turkey, which is located on the north - west part of the Marmara Region, is known as an agricultural region and there are very large agricultural lands because of its quite rich soil and numbers of freshwater resources. The Ergene River Basin, which is the most important river basin of the Thrace Region, contains many industrial enterprises on its watershed and as well as the majority of these facilities are located on the upstream of the basin. Therefore, in addition to the agricultural pressure, industrial activities are also one of the significant pollution 
factors for the basin (Tokatlı, 2015; Sarı et al., 2016; Tokatlı and Baştatlı, 2016). Altınyazı, Karaidemir, Kayalıköy, Kırklareli, Sultanköy and Süloğlu Dam Lakes are located on the Ergene River Basin and they are the most important reservoirs of the Thrace Region. They were constructed by DSi (State Water Works), on the Basamaklar, Poğaça, Teke, Şeytandere, Manastır and Süloğlu Streams respectively in order to provide irrigation and drinking water and also flood protection for the local settlements (http://www.dsi.gov.tr/). But as many freshwater ecosystems, these reservoirs are also being affected by especially agricultural and domestic pressure.

As many freshwater ecosystems, all these reservoirs are being adversely affected by especially agricultural and domestic pressure. The aim of this study was to reveal that pressure on these six significant artificial lentic habitats located on the Ergene River Basin by determining macro - micro element accumulations in sediment samples and evaluate the sediment quality by using Potential Ecological Risk Index.

\section{MATERIALS AND METHODS}

Study Area and Collection of Samples

Sediment samples were collected from 15 stations selected on the reservoirs in the rainy (spring) season of 2018. Topographic map of Ergene River Basin and Altınyazı, Karaidemir, Kayalıköy, Kırklareli, Sultanköy and Süloğlu Dam Lakes and selected stations on the reservoirs are given in Figure 1. Sediment samples were collected form the upper $10 \mathrm{~cm}$ of sediments with an ekman grab sampler in $1 \mathrm{~L}$ sterile glass bottles and kept at $4{ }^{\circ} \mathrm{C}$ until the chemical analysis.

\section{Chemical Analysis}

Sediment samples were dried for 3 hours at $105^{\circ} \mathrm{C}$. Samples were placed ( $0.25 \mathrm{gr}$ of each sample) in Pyrex reactors of a CEM Mars Xpress 5 microwave digestion unit. $\mathrm{HClO}_{4}: \mathrm{HNO}_{3}$ acids of $1: 3$ proportions were inserted in the reactors respectively. Samples were mineralized at $200{ }^{\circ} \mathrm{C}$ for thirty minutes. Afterwards, the samples were filtered in such a way as to make their volumes to $100 \mathrm{ml}$ with ultra - pure distilled water. The element levels in the sediment samples were determined by using the "Agilent 7700 xx" branded Inductively Coupled Plasma - Mass Spectrometer (ICP - MS) device at the Trakya University Technology Research and Development Application and Research Center (TÜTAGEM). The center has an international accreditation certificate within the scope of TS EN / ISO IEC 17025 issued by

\section{ERGENE BASIN}

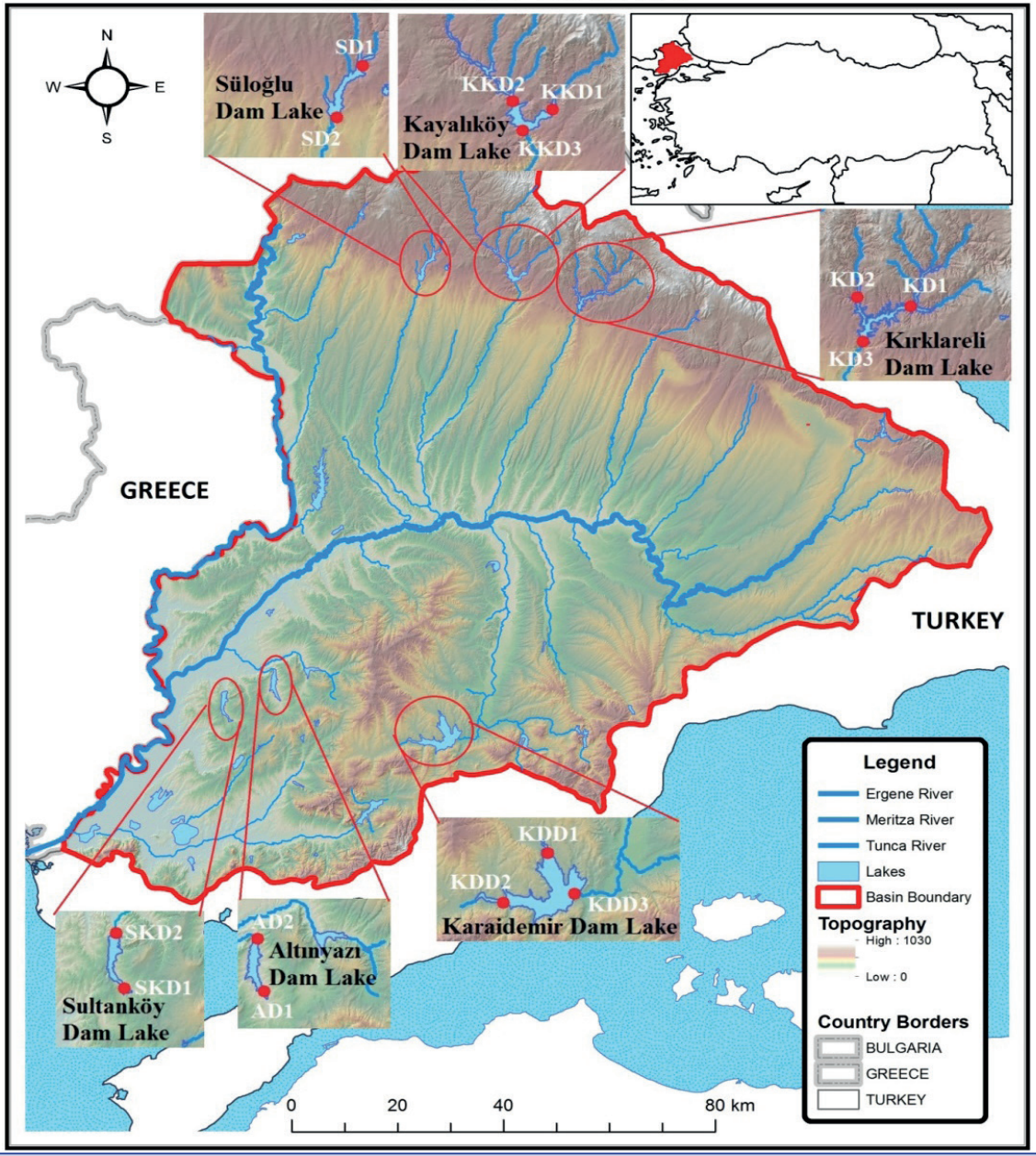

Figure 1. Topographic map of Ergene River Basin and selected stations. 
TÜRKAK (representative of the World Accreditation Authority in Turkey). The element analyses were recorded as means triplicate measurements (EPA, 1998; 2001).

\section{Potential Ecological Risk Index $\left(\mathbf{R}_{\mathbf{l}}\right)$}

The Potential Ecological Risk Index was developed to evaluate the ecological risks in sediment samples in order to control the aquatic contamination. The methodology is based on the assumption that the sensitivity of the aquatic system depends on its productivity. According to the toxicity of toxic elements and the response of the environment, it was introduced to evaluate the degree of heavy metal pollution in sediments. The Potential Ecological Risk Index $\left(R_{1}\right)$ can be calculated with the following formula (Hakanson, 1980);

$$
R_{1}=\sum E_{r}^{i} \quad E_{r}^{i}=T_{r}^{i} C_{f}^{i} \quad C_{f}^{i}=C_{0}^{i} / C_{n}^{i}
$$

Where

" $R_{\mid}$" is calculated as the sum of all risk factors for heavy metals in sediments,

" $E_{r}^{i}$ " is the monomial potential ecological risk factor,

" $\mathrm{T}^{\mathrm{i}}$ " is the toxic response factor for a given substance (Table 3), " $\mathrm{C}_{f}{ }^{\mathrm{f}}$ " is the contamination factor, " $\mathrm{C}_{0}^{\mathrm{i}}$ " is the concentration of metals in the sediment and

" $\mathrm{C}_{n}^{\mathrm{i}}$ " is a reference value for metals (Table 3 ).

The scale of " $\mathrm{R}_{1}$ " was given in Table 1 .

Table 1. Scale used to describe the risk factors of $E_{r}^{i}$ and $R_{1}$ (Hakanson, 1980)

\begin{tabular}{cccc}
\multicolumn{4}{c}{ Assessment of potential ecological risk } \\
\hline$E_{r}^{i}$ & Potential ecological risk for monomial factor & $R_{1}$ & Potential ecological risk for multinomial factors \\
$<40$ & Low ecological risk & $<95$ & Low ecological risk \\
$40-80$ & Moderate ecological risk & $95-190$ & Moderate ecological risk \\
$80-160$ & Considerable ecological risk & $190-380$ & Considerable ecological risk \\
$160-320$ & High ecological risk & $>380$ & Very high ecological risk \\
$>320$ & Very high ecological risk & &
\end{tabular}

Table 2. Macro - micro element accumulations in artificial lacustrine habitats in the Ergene River Basin

\begin{tabular}{|c|c|c|c|c|c|c|c|c|c|c|c|c|c|c|c|}
\hline \multirow{2}{*}{$\begin{array}{c}\text { Elements } \\
(\mathrm{mg} / \mathrm{kg})\end{array}$} & \multicolumn{8}{|c|}{ Northern Dam Lakes } & \multicolumn{7}{|c|}{ Southern Dam Lakes } \\
\hline & SD1 & SD2 & KD1 & KD2 & KD3 & KKD1 & KKD2 & KKD3 & KDD1 & KDD2 & KDD3 & AD1 & AD2 & SKD1 & SKD2 \\
\hline $\mathrm{Li}$ & 35.4 & 94.4 & 97.3 & 115.4 & 80.0 & 148.9 & 199.9 & 345.1 & 113.5 & 149.6 & 56.3 & 162.1 & 225.5 & 104.6 & 103.7 \\
\hline $\mathrm{Be}$ & 5.627 & 10.648 & 23.524 & 11.582 & 22.043 & 25.019 & 17.532 & 11.224 & 8.573 & 10.567 & 5.341 & 13.304 & 13.948 & 18.119 & 25.215 \\
\hline B & 60.752 & 61.216 & 71.660 & 56.383 & 45.305 & 41.864 & 68.680 & 214.041 & 60.285 & 79.271 & 60.052 & 66.166 & 59.285 & 60.839 & 62.013 \\
\hline Al & 17011 & 98996 & 88745 & 92120 & 96885 & 204821 & 340876 & 173009 & 71847 & 116657 & 28218 & 95666 & 163288 & 138604 & 175258 \\
\hline K & 6323 & 56044 & 34535 & 18592 & 39543 & 23928 & 55484 & 37016 & 32644 & 43227 & 9079 & 12240 & 17747 & 23371 & 34860 \\
\hline $\mathrm{Ca}$ & 38058 & 56341 & 86844 & 28625 & 79668 & 119225 & 2550992 & 2452257 & 25136 & 83399 & 17020 & 667195 & 1717582 & 999325 & 593793 \\
\hline v & 103.1 & 333.0 & 297.1 & 210.9 & 252.8 & 930.1 & 788.9 & 828.8 & 229.3 & 372.8 & 83.6 & 230.2 & 521.7 & 661.1 & 649.2 \\
\hline $\mathrm{Cr}$ & 78.6 & 186.9 & 136.8 & 98.4 & & 777.1 & 407.3 & & 105.6 & & 62.9 & 562.9 & 741.4 & 362.4 & 358.5 \\
\hline $\mathrm{Cu}$ & 31.2 & 135.9 & 436.6 & 58.6 & 135.3 & 504.5 & 464.0 & 257.8 & 81.1 & 345.9 & 22.2 & 142.3 & 257.3 & 220.0 & 228.0 \\
\hline $\mathrm{Zn}$ & 410 & 601 & 1254 & 585 & 716 & 891 & 1045 & 595 & 600 & 1178 & 321 & 696 & 850 & 564 & 612 \\
\hline As & 18.623 & 20.341 & 28.661 & 21.710 & 729.450 & 89.164 & 53.428 & 40.698 & 12.181 & 33.600 & 9.372 & 13.653 & 42.091 & 69.270 & 59.219 \\
\hline $\mathrm{Se}$ & 116 & 113 & 110 & 107 & 110 & 112 & 109 & 113 & 105 & 104 & 106 & 108 & 106 & 112 & 118 \\
\hline $\mathrm{Sr}$ & 126 & 297 & 198 & 132 & 268 & 1117 & 10938 & 8000 & 128 & 625 & 93 & 1476 & 3381 & 1421 & 1405 \\
\hline Mo & 48.205 & 47.912 & 47.325 & 46.616 & 52.408 & 46.586 & 47.070 & 212.363 & 45.042 & 47.974 & 45.111 & 43.762 & 44.164 & 43.571 & 45.329 \\
\hline $\mathrm{Cd}$ & 1.170 & 2.225 & 12.517 & 1.788 & 3.818 & 6.235 & 5.144 & 7.594 & 1.428 & 3.577 & 0.585 & 1.772 & 3.320 & 3.181 & 2.995 \\
\hline $\mathrm{Sb}$ & 0.461 & 0.845 & 2.052 & 0.427 & 0.534 & 0.660 & 0.463 & 183.661 & 1.182 & 1.187 & 0.441 & 0.471 & 0.335 & 0.562 & 0.671 \\
\hline $\mathrm{Ba}$ & 709 & 2615 & 1252 & 499 & 3440 & 6796 & 9378 & 3311 & 731 & 3411 & 504 & 1124 & 3462 & 5688 & 4449 \\
\hline $\mathrm{TI}$ & 0.589 & 3.007 & 3.475 & 1.690 & 2.234 & 4.885 & 1.882 & 6.383 & 2.271 & 2.287 & 0.939 & 1.027 & 2.142 & 1.222 & 1.793 \\
\hline $\mathrm{Pb}$ & 166 & 360 & 1764 & 355 & 529 & 1145 & 434 & 431 & 204 & 398 & 72 & 138 & 417 & 620 & 504 \\
\hline
\end{tabular}




\section{RESULTS AND DISCUSSION}

Essential and toxic element accumulations detected in sediments of reservoirs located in the Ergene River Basin are given in Table 2. The Potential Ecological Risk Index monomial $\left(E_{r}^{i}\right)$ and multinomial $\left(R_{1}\right)$ for each station selected on the dam lakes located on the Ergene River Basin were identified and all the results are given in Table 3.

According to the results of monomial potential ecological risk in$\operatorname{dex}\left(E_{r}^{i}\right)$, all the investigated toxic elements posed "low ecological risk" on the reservoirs. The Potential Ecological Risk Index for monomial regulators indicted that the intensity of the investigated toxic metals can be followed as $\mathrm{Cd}>\mathrm{Pb}>\mathrm{As}>\mathrm{Cu}>\mathrm{Cr}>\mathrm{Zn}$. According to the results of multinomial potential ecological risk index $\left(R_{1}\right)$, all the investigated stations exhibited "low ecological risk". The Potential Ecological Risk Index for multinomial regulators indicted that the ecological risks of the system can be followed as Kırklareli Dam Lake > Kayalıköy Dam Lake > Sultanköy Dam Lake > Altınyazı Dam Lake > Karaidemir Dam Lake > Süloğlu Dam Lake (Figure 2).

Cadmium is an agricultural origin toxic metal and it is known that it can be easily emitted to soil and water by using phosphate fertilizers. Cadmium, which may accumulate in aquatic organisms and agricultural crops, can also bind strongly to organic matter and be taken up by plant life and can be included in the food chain. It is clearly known that pesticides have a significant impact on lead and arsenic transition to the water, soil and sediment and also fertilizers contain significant quantities of zinc and copper
(ATSDR, 2004; 2005a; 2005b; 2007). The Thrace Part of the Marmara Region is known as a significant agricultural zone in Turkey and has very large agricultural lands because of its rich soil and much ground - surface freshwater resources. In the present study, as a result Potential Ecological Risk Index, cadmium, lead and arsenic, which are known as agricultural origin toxicants, were found to be the most risky elements for the sediments of dam lakes located in the Ergene River Basin. The most significant anthropogenic sources of chromium in freshwater ecosystems is known as industrial activities, which are being intensively performed around the upstream of the Ergene River Basin (especially in the Çorlu and Çerkezköy Distrits) (ATSDR, 2000). According to the results of the Potential Ecological Risk Index, chromium did not pose a significant risk factor for the sediments of the investigated reservoirs. These results reflect that the dam lakes of the Thrace Region are not being affected significantly by the intensive industrial activities conducted around the Ergene River Basin.

In a study performed in the Gala Lake National Park (Meriç - Ergene River Basin) in Turkey, the Potential Ecological Risk Index was used to evaluate the sediment quality. As a result of this study, similar to the present study, cadmium was found to be the most risky element for the Gala Lake (Tokatlı, 2017). According to the results of another Potential Ecological Risk Index application conducted in Seydisuyu Stream Basin, similar to the results of the present study, chromium and cadmium were reported as the most risky elements for the Seydisuyu Stream Basin (Tokatlı et al., 2017b). Soliman et al. (2015) assessed the potential ecological risks of heavy metals in sediments of the Mediterranean coast in

Table 3. Toxic metal risk index values in sediments of the reservoirs

\begin{tabular}{|c|c|c|c|c|c|c|c|c|c|}
\hline \multirow{2}{*}{ Dam Lakes } & \multirow{2}{*}{ Stations } & \multicolumn{6}{|c|}{$\mathrm{E}_{\mathrm{r}}^{\mathrm{i}}$} & \multirow{2}{*}{$\mathbf{R}_{\mathbf{l}}$} & \multirow{2}{*}{$\begin{array}{c}\text { Multinomia } \\
\text { Mean }\end{array}$} \\
\hline & & As & $\mathrm{Cr}$ & $\mathrm{Cu}$ & $\mathrm{Pb}$ & $\mathrm{Zn}$ & $\mathrm{Cd}$ & & \\
\hline \multirow[t]{2}{*}{ Süloğlu } & SD1 & 0.012 & 0.003 & 0.005 & 0.033 & 0.005 & 0.070 & 0.129 & 0.192 \\
\hline & SD2 & 0.014 & 0.006 & 0.023 & 0.072 & 0.008 & 0.133 & 0.255 & \\
\hline \multirow[t]{3}{*}{ Kırklareli } & KD1 & 0.019 & 0.005 & 0.073 & 0.353 & 0.016 & 0.751 & 1.216 & 0.761 \\
\hline & KD2 & 0.014 & 0.003 & 0.010 & 0.071 & 0.007 & 0.107 & 0.213 & \\
\hline & KD3 & 0.486 & 0.003 & 0.023 & 0.106 & 0.009 & 0.229 & 0.855 & \\
\hline \multirow[t]{3}{*}{ Kayalıköy } & KKD1 & 0.059 & 0.026 & 0.084 & 0.229 & 0.011 & 0.374 & 0.784 & 0.654 \\
\hline & KKD2 & 0.036 & 0.014 & 0.077 & 0.087 & 0.013 & 0.309 & 0.535 & \\
\hline & KKD3 & 0.027 & 0.025 & 0.043 & 0.086 & 0.007 & 0.456 & 0.644 & \\
\hline \multirow[t]{3}{*}{ Karaidemir } & KDD1 & 0.008 & 0.004 & 0.014 & 0.041 & 0.008 & 0.086 & 0.159 & 0.208 \\
\hline & KDD2 & 0.022 & 0.009 & 0.058 & 0.080 & 0.015 & 0.215 & 0.398 & \\
\hline & KDD3 & 0.006 & 0.002 & 0.004 & 0.014 & 0.004 & 0.035 & 0.065 & \\
\hline \multirow[t]{2}{*}{ Altınyazı } & AD1 & 0.009 & 0.019 & 0.024 & 0.028 & 0.009 & 0.106 & 0.194 & 0.291 \\
\hline & AD2 & 0.028 & 0.025 & 0.043 & 0.083 & 0.011 & 0.199 & 0.389 & \\
\hline \multirow[t]{2}{*}{ Sultanköy } & SKD1 & 0.046 & 0.012 & 0.037 & 0.124 & 0.007 & 0.191 & 0.417 & 0.397 \\
\hline & SKD2 & 0.039 & 0.012 & 0.038 & 0.101 & 0.008 & 0.180 & 0.378 & \\
\hline \multicolumn{2}{|c|}{ Monomial Mean } & 0.055 & 0.011 & 0.037 & 0.100 & 0.009 & 0.229 & & \\
\hline \multicolumn{2}{|c|}{${ }^{*} \mathrm{C}_{\mathrm{n}}^{\mathrm{i}}$} & 15.00 & 60.00 & 30.00 & 25.00 & 80.00 & 0.50 & & \\
\hline \multicolumn{2}{|c|}{$* T_{r}^{{ }^{n}}$} & 10.00 & 2.00 & 5.00 & 5.00 & 1.00 & 30.00 & & \\
\hline
\end{tabular}




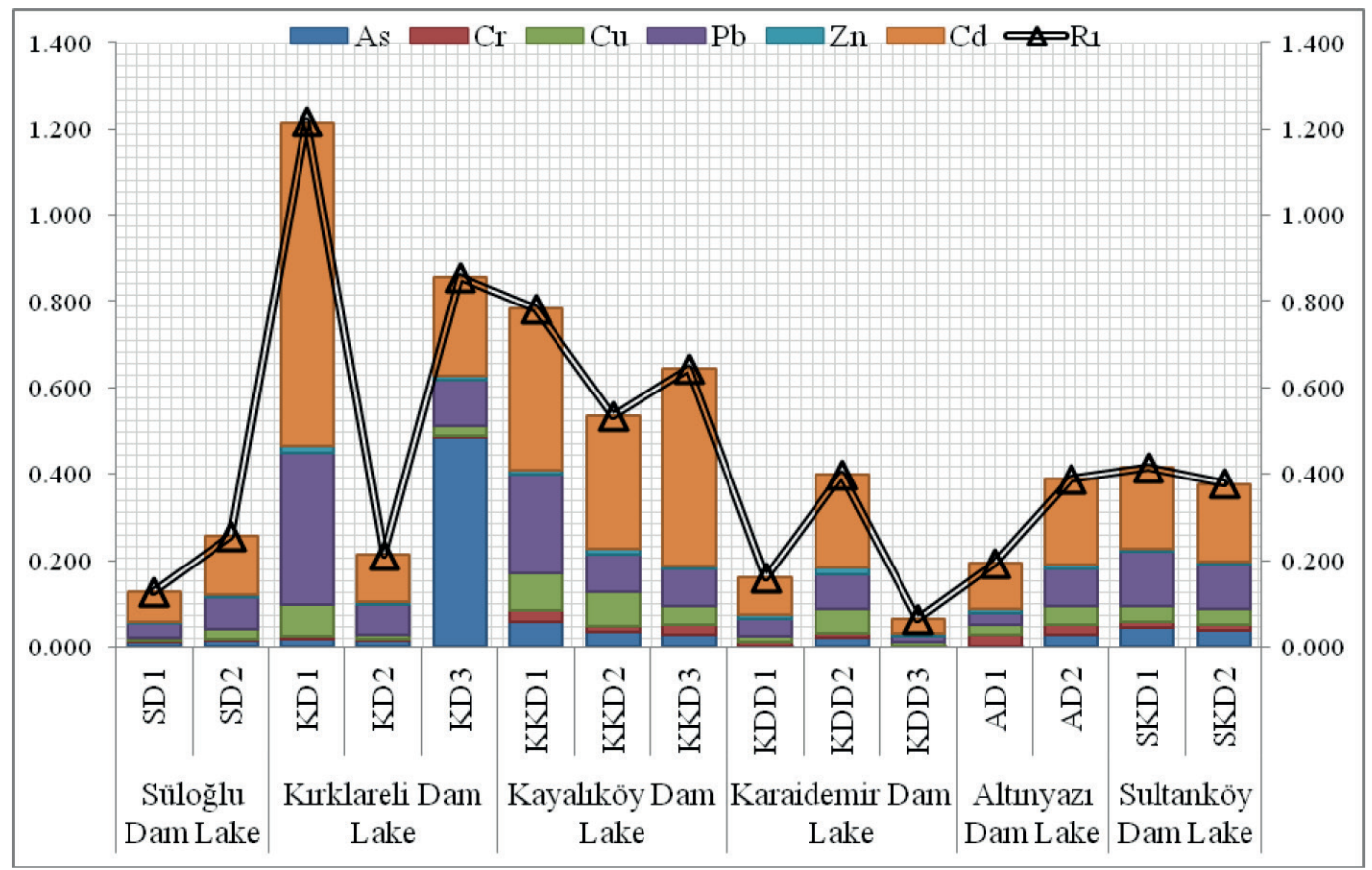

Figure 2. Values of Potential Ecological Risk Index.

Egypt and, similar to the present study, the risk assessment of this study showed that $\mathrm{Cd}$ had the highest ecological risk $(\mathrm{Er}=21.52)$, followed by $\mathrm{Pb}(\mathrm{Er}=3.01)$, while $\mathrm{Zn}$ had the lowest risk $(\mathrm{Er}=0.23)$.

In a study performed in Turkey, cadmium contents of different fertilizer samples taken from different fertilizer factories were investigated. It was reported that cadmium residues of many fertilizers used in Turkey were found to be over the limit values notified for fertilizers. It is known that phosphate rocks are the main ingredient of phosphate fertilizers and they are being imported from abroad to Turkey (Köleli and Kantar, 2005). Cadmium concentrations of these imported phosphate rocks are much more than what they should be. As a result of using phosphate fertilizers based of these imported phosphate rocks, significant amounts of cadmium are being accumulated on the land surface and also being moved to surface and groundwater resources (Emiroğlu et al., 2013).

The Thrace Region is known as one of the most productive lands in Turkey. Rice and sunflower are the two main crops produced in the region. Edirne City is also known as the most important city for rice production in Turkey. But unfortunately, agricultural applications carried out in the basin have been generally performed in the form of monoculture applications for many years (Helvacıoğlu et al., 2015). This situation causes the decrease of soil quality and increase in the use of fertilizers, and may be the reason for the detected quite high cadmium accumulations in regional sediments.

\section{CONCLUSIONS}

In this study, the Potential Ecological Risk Index was used to evaluate the sediment quality of the most significant artificial la- custrine habitats of the Ergene River Basin. According to results of Potential Ecological Risk Index, cadmium, lead and arsenic were found to be the highest ecological risk factors for the dam lakes and the ecological risk levels of the investigated reservoirs were recorded as; Kırklareli > Kayalıköy > Sultanköy > Altınyazı $>$ Karaidemir > Süloğlu in general. The data of this research reveals that agricultural runoff caused by pesticide and fertilizer applications because of mainly monoculture practices conducted almost all around the region was the main ecological risk for the sediment qualities of the reservoirs located in the Ergene River Basin. Also, the present study clearly presents the necessity and availability of sediment indices on freshwater sediment quality assessment studies. In order to improve the sediment qualities of these significant artificial lentic ecosystems, monoculture practices in agricultural applications should be changed and the local people should be encouraged to use polyculture practices. Also, the uninformed use of chemical fertilizers and pesticides should be avoided by giving the necessary training to the farmers.

Financial Disclosure: The present study was funded by the Trakya University, Commission of Scientific Research Projects (Project No. 2017/211).

Conflict of Interest: The author has no conflicts of interest to declare.

\section{REFERENCES}

ATSDR (Agency for Toxic Substances and Disease Registry) (2000). Toxicological profile for chromium. Atlanta, GA: U.S. Department of Health and Human Services. https://www.atsdr.cdc.gov/ (accessed 05.03.2019). 
ATSDR (Agency for Toxic Substances and Disease Registry) (2004). Toxicological profile for copper. Atlanta, GA: U.S. Department of Health and Human Services. https://www.atsdr.cdc.gov/ (accessed 05.03.2019).

ATSDR (Agency for Toxic Substances and Disease Registry) (2005a). Toxicological profile for arsenic. Atlanta, GA: U.S. Department of Health and Human Services. https://www.atsdr.cdc.gov/ (accessed 05.03.2019).

ATSDR (Agency for Toxic Substances and Disease Registry) (2005b). Toxicological profile for zinc. Atlanta, GA: U.S. Department of Health and Human Services. https://www.atsdr.cdc.gov/ (accessed 05.03.2019).

ATSDR (Agency for Toxic Substances and Disease Registry) (2007). Toxicological profile for cadmium. Atlanta, GA: U.S. Department of Health and Human Services. https://www.atsdr.cdc.gov/ (accessed 05.03.2019).

Çiçek, A., Köse, E., Emiroğlu, Ö., Tokatlı, C., Başkurt, S. \& Sülün, Ş. (2014). Boron and arsenic levels in water, sediment and tissues of Carassius gibelio (Bloch, 1782) in a dam lake. Polish Journal of Environmental Studies, 23(5), 1843-1848.

Çiçek, A., Köse, E. \& Tokatlı, C. (2019). Use of factor analysis to evaluate the sediment quality of a significant mining area: Seydisuyu Stream Basin (Turkey). Polish Journal of Environmental Studies, 28(3), 20212025. [CrossRef]

Çiçek, A., Tokatlı, C. \& Köse, E. (2013). Ecological risk assessment of heavy metals in sediment of Felent Stream (Sakarya River Basin, Turkey). Pakistan Journal of Zoology, 45(5), 1335-1341.

Environmental Protection Agency (EPA) METHOD 3051A. (1998). Microwave assisted acid digestion of sediments, sludges, soils, and oils. https://www.epa.gov/ (accessed 03.03.2019)

Environmental Protection Agency (EPA) METHOD 200.7. (2001). Determination of metals and trace elements in water and wastes by Inductively coupled plasma-atomic emission spectrometry. https:// www.epa.gov/ (accessed 03.03.2019).

Emiroğlu, Ö., Uyanoğlu, M., Başkurt, S., Sülün, Ş., Köse, E., Tokatlı, C., Uysal, K., Arslan, N. \& Çiçek, A. (2013). Erythrocyte deformations in Rutilus rutilus (Linnaeus, 1758) provided from Porsuk Dam (Turkey). Biological Diversity and Conservation, 6(1), 13-17.

Farombi, E. O., Adelowo, O. A. \& Ajimoko. Y. R. (2007). Biomarkers of oxidative stress and heavy metal levels as indicators of environmental pollution in African cat fish (Clarias gariepinus) from Nigeria ogun river. International Journal of Environmental Research and Public Health, 4(2), 158-165. [CrossRef]

Håkanson, L. (1980). An ecological risk index for aquatic pollution control of sediment ecological approach. Water Research, 14, 975-1000. [CrossRef]

Helvacıoğlu, I. A., Şener, T., Tokatlı, C. \& Balkan, A. (2015). Economic review of production possibilities and production costs of rice in "Ipsala Karpuzlu - Meriç" region. 3rd International Conference on Agriculture \& Food, 1-5 June 2015, Elenite Holiday Village, Bulgaria, 193-201. http://www.dsi.gov.tr/ (accessed 03.03.2019). T.C. State Water Works Official Web Site. 11. Regional Directorate, Dams and Ponds.

Köleli, N. \& Kantar, Ç. (2005). Fosfat kayasi, fosforik asit ve fosforlu gübrelerdeki toksik ağir metal $(\mathrm{Cd}, \mathrm{Pb}, \mathrm{Ni}, \mathrm{As})$ konsantrasyonu. Ekoloji, 14, 55, 1-5.

Köse, E., Tokatlı, C. \& Çiçek, A. (2014). Monitoring stream water quality: a statistical evaluation. Polish Journal of Environmental Studies, 23(5), 1637-1647.

Maanan, M., Barjy, M. E., Hassou, N., Zidane, H., Zourarah, B. \& Maanan, M. (2018). Origin and potential ecological risk assessment of trace elements in the watershed topsoil and coastal sediment of the Oualidia lagoon, Morocco. Human and Ecological Risk Assessment: An International Journal, 24(3), 602-614. [CrossRef]

Sari, E., Cukrov, N., Frančišković-Bilinski, S., Kurt, M. A. \& Halli, M. (2016). Contamination assessment of ecotoxic metals in recent sediments from the Ergene River, Turkey. Environmental Earth Sciences, 75, 1051. [CrossRef]

Soliman, N., F., Nasr, S., M. \& Okbah, M. A. (2015). Potential ecological risk of heavy metals in sediments from the Mediterranean coast, Egypt. Journal of Environmental Health Science and Engineering, 13, 70. [CrossRef]

Tokatlı, C. (2015). Assessment of the water quality in the Meriç River: as an element of the ecosystem in the Thrace Region of Turkey. Polish Journal of Environmental Studies, 24(5), 2205-2211. [CrossRef]

Tokatlı, C. (2017). Bio - ecological and statistical risk assessment of toxic metals in sediments of a worldwide important wetland: Gala Lake National Park (Turkey). Archives of Environmental Protection, 43(1), 34-47. [CrossRef]

Tokatlı, C. \& Baştatlı, Y. (2016). Trace and toxic element levels in river sediments. Polish Journal of Environmental Studies, 25(4), 1715-1720. [CrossRef]

Tokatlı, C., Baştatlı, Y. \& Elipek, B. (2017a). Water quality assessment of dam lakes located in Edirne province (Turkey). Sigma Journal of Engineering and Natural Sciences, 35(4), 743-750.

Tokatlı, C., Çiçek, A., Köse, E. (2017b). Use of bio - ecological risk indices to evaluate the sediment quality of seydisuyu stream basin. Iğdır University Journal of the Institute of Science and Technology, 7(2), 267-275. [CrossRef]

Tokatlı, C., Köse, E., Arslan, N., Çiçek, A., Emiroğlu, Ö. \& Dayıoglu, H. (2016). Ecosystem quality assessment of an aquatic habitat in a globally important boron reserve: Emet Stream Basin (Turkey). International Journal of Environment and Pollution, 59(2/3/4), 116141. [CrossRef]

Yu, G. B., Liu, Y., Yua, S., Wuc, S.C., Leung A. O. W., Luo, X. S., Xua, B., Li, H. B. \& Wongc, M. H. (2011). Inconsistency and comprehensiveness of risk assessments for heavy metals in urban surface sediments. Chemosphere, 85, 1080-1087. [CrossRef] 